\title{
The Effectiveness of a Micro-Learning Strategy in Developing the Skills of Using Augmented Reality Applications among Science Teachers in Jeddah
}

\author{
Ali bin Muhammad Al-Kalthmi Al-Shehri
}

\section{ARTICLE INFO}

Article History:

Received 20.04.2020

Received in revised form

28.01.2021

Accepted

Available online

01.04.2021

\begin{abstract}
This study aimed at identifying the effectiveness of a micro-learning strategy-based instructional program in developing the skills of using augmented reality applications among science teachers in Jeddah. The study used the semi-experimental approach based on the experimental design of one group (pre-posttests), and the instruments were an achievement test and the observation card. The sample of the study consisted of (42) science teachers in the intermediate stage in Jeddah. After conducting the study, the results showed statistically significant differences between the mean scores of the study group in the pre and post-application of the achievement test and the observation card on the skills of using augmented reality applications. The differences were in favor of the posttest. The study recommended the importance of the micro-learning strategy in providing advanced practical solutions to training and education problems in line with modern technological development
\end{abstract}

(C) IJERE. All rights reserved

Keywords: ${ }^{1}$

Training program, micro-learning strategy, augmented reality applications, science teachers, Jeddah.

\section{INTRODUCTION}

The continuous development of information and communication technology has led to great changes in the educational environment. Face-to-face interaction under traditional education is replaced by online educational interactions. The traditional whiteboard and printed materials have been replaced by various digital sources available through various electronic platforms. Therefore, teachers are not only required to possess a full understanding of educational theories and their educational applications but rather they are expected to possess the appropriate technical skills to use and employ various e-learning tools and environments in education (Duman \& Karagöz,2016; Eyong, Ugada \& Aminu,2020; Tschida, Hodge \& Schmidt, 2016). Ghavifekr and Rosdy (2015) explained that there is a significant impact of teachers' use of technologies on learners. Technology does not limit teachers to curricula and resources, but rather provide them with electronic motivational activities that increase their motivation to learn, arouse their attention, integrate them positively in the educational process and make them in a state of permanent activity. Augmented reality applications are technologies that allow the integration of real and virtual reality and provide real-time support to the learner. This technology provides visual support for the learner, kinetic and visual learning, real learning, and individual learning experiences (Matcha \& Rambli, 2013). The augmented reality applications support the learning process and develop the learners' skills visually. Learners can achieve better academic results, improve their knowledge and increase their performance skills (Gómez \& Paredes, 2019). These applications embody and depict abstract concepts according to the levels of understanding of learners and enable them to observe existing phenomena, which are impossible to sees in real life (Arici, Yildirim, Caliklar \& Yilmaz, 2019). Because of the educational characteristics, advantages, and efficacy of augmented reality applications, teachers' acquisition of these skills during service to be used in teaching is a necessity and imperative in light of their widespread use. Other studies indicated the need to develop teachers 'skills to use augmented reality applications as basic skills to support the educational process (Al-Zein, 2018; Al-Shami \& Al-Qadi, 2017). The micro-learning strategy is suitable for implementing e-training programs, especially for teachers, as this strategy focuses on practical activities and exercises rather than on theoretical aspects, which is consistent with the training characteristics and standards (Faraj, 2019). The micro-learning training strategy is defined as an educational system that includes a set of planned and structured experiences presented in short educational videos with activities, short exercises, and simultaneous and asynchronous interactions using mobile devices. This strategy aims to develop the knowledge, skills, and attitudes required by a group of individuals in a specific field according to their needs (Abu Khotwa, 2020). This strategy also aims to provide the knowledge that the trainee needs to apply in

Corresponding e-mail: alialshehri20222@gmail.com, orcid.org/0000-0002-1484-2175

Department of Educational Technologies College of Education - University of Jedda Saudi Arabia 
practical or real-life situations, and which is re-used in other training contexts and available upon request (Kävrestad \& Nohlberg, 2019). The micro-learning strategy facilitates knowledge acquisition in the workplace by engaging and motivating trainees to communicate and apply what they have learned (Emerson \& Berge, 2018). It also helps improve motivation (Shail, 2019), improves the trainees' involvement in the training process (Nikou, 2019), and helps to increase feelings of confidence and accuracy in performances (Hesse, Ospina, Wieland, Yepes, Nguyen \& Heuwieser, 2019).

As part of the results of the COVID-19 pandemic, thousands of schools were closed, and online learning was the main inevitable and only option for teaching. This shift led to great challenges facing teachers in adapting to teaching through e-learning tools and applications, maintaining a minimum level of communication with learners, and supporting them (König, Jäger-Biela \& Glutsch, 2020). Augmented reality applications are effective e-learning applications in education in general and in science education in particular. Yildirim (2020) confirmed its effectiveness in developing academic achievement in science. Wahyu, Suastra, Sadia and Suarni (2020) concluded that combining this strategy with the stem approach leads to the development of scientific literacy and achievement. Azi and Gemseddin (2020) found its effectiveness in developing trends. Other several studies emphasized the need to develop skills in using augmented reality applications among teachers (Al-Zein, 2018; Al-Shami \& Al-Qadi, 2017). The microlearning strategy is also one of the modern and advanced training strategies. In teaching science, many studies have emphasized the necessity of using it in teacher training, and its effectiveness in training science teachers before and during service (Wali, 2020; Farag, 2019; Bakır, 2014).

The roots of micro-learning go back to the sixties, but they were not further embodied and clear until the emergence of the term second generation of the web. This technology, including its tools and applications, formed the fertile ground for the spread of the term micro-learning, as it relied on the different forms of micro-content, which depended on the use of a certain number of words such as Twitter, or the presence of podcasts through Facebook (Díaz, Caeiro, López \& Vilas, 2021). The micro-learning strategy relies on designing relatively small focused educational units that include intensive educational activities (from one to ten minutes), and are available across multiple devices (Shail, 2019). The micro-learning strategy is based on seven dimensions. Firstly, time should be presented in small periods. Secondly, the content, which is presented in short units with specific topics. Thirdly, the curriculum, which includes brief educational elements. Fourthly, the form, which presents varied formats. Fifthly, the treatment, which shows that the activities as independent or integrated. Sixthly, the media, which presents varied multiple media. Seventhly, education models, which are constructive and communicative and achieve learning objectives (Hug, 2006). The advantage of the micro-learning strategy is that it can be presented in short periods and requires little effort. It can include simple topics funnily and attractively and can be updated easily. It is also a way to solve educational or training problems interactively and available at any time and place (Jomah, Masoud, Kishore \& Aurelia, 2016; Mahmud \& Rawshon, 2013).

The term augmented reality first appeared in the 1950s when Morton Heilig, a cinematographer, believed that cinema as art should be able to draw the viewer into screen activity. The prototypes of augmented reality were made in the 1960s and the use of 3D graphics was created by Ivan Sutherland and his students at Harvard University and the University of Utah (Alkhamisi \& Monowar, 2013). Augmented reality is an environment that includes both elements of virtual reality and the real world, as it allows the user to see the real world by creating virtual objects that merge with the real world (Chen, 2014). The term augmented reality differs from the term virtual reality, and the essential point of this difference is due to immersion. Virtual reality uses masks and special glasses that immerse the learner in learning and try to convince them that they are inside a real reality, so it becomes a reasonably convincing illusion. Augmented reality, on the contrary, does not dispense with the real world, but uses computers to improve it in different ways (Kulkarni \& Takawale, 2016). Despite the many reasons for using augmented reality applications, one of the most important is that it no longer requires expensive devices and advanced equipment, such as the head-mounted device (HMD). This technology can be used with computers or mobile devices, and so on. Augmented reality technology is not as difficult as it was in the past, to the point that it can be used today at every level of education, from kindergartens to the university level (Akçayır \& Akçayır, 2017).

Designing a scene in augmented reality applications is an attractive creative experience that can demonstrate practical design skills in three-dimensional form and help in developing the design and 
problem-solving skills of learners (Billinghurst \& Dünser, 2012). It allows the inclusion of educational experiences in the real world environment and by bringing the real world to the classroom (Chen \& Tsai, 2012). Akçayır \& Akçayır (2017) analyzed studies that dealt with augmented reality from the period (20112017) to identify the advantages and challenges of augmented reality in education. Their study concluded that the advantages of augmented reality are enhancing educational attainment and motivation to Learning, helping learners to understand, and providing a positive attitude. Many studies have dealt with the variables of the current study. Wali (2020) designed a portable micro-learning program based on synchronous and asynchronous interactive video and measured its effectiveness in developing the achievement and self-directed learning skills of students of the Faculty of Education. The study sample consisted of (168) students, who were divided into three groups one control and two experimental groups. The first experimental group learned through the micro-learning program based on simultaneous interactive video. The second experimental group learned through the micro-learning program based on asynchronous interactive video. The study found differences between the three groups in the post-application of the achievement test for the benefit of students of the first experimental group, which learned through the micro-learning based on simultaneous interactive videos. The study also found differences between the three study groups in the post-application of the self-directed learning skills scale in favor of students of the second experimental group that used the asynchronous interactive video-based micro-learning program. Ahmad (2019) identified the effect of using WhatsApp as a tool for a micro-learning strategy for developing achievement and revealing learners' opinions about its use in education. The study sample consisted of (30) students who were divided into two groups, an experimental group of (15), which used WhatsApp as a tool for the micro-learning strategy, and a control group (15), which used the traditional method. The study found that the performance of the experimental group exceeded the control group in the achievement test as a result of their use of WhatsApp as a tool for the micro-learning strategy and that the learners' opinions about its use in education were positive. Faraj (2019) explored the impact of electronic micro-training technology via the web on developing the cognitive and performance aspect of the competencies of designing e-learning strategies among secondary education teachers. The study sample consisted of (20) teachers as one experimental group. The study found a significant technological impact of micro-electronic training via the web on developing the knowledge and performance dimensions of the competencies of designing e-learning strategies for secondary education teachers. Nikou and Economides (2018) identified the impact of the mobile micro-learning strategy on developing achievement and motivation among high school students. The study sample consisted of (108) students who were divided into two groups, an experimental group using the mobile micro-learning strategy, and a control group using the traditional method. The study revealed the superiority of the experimental group over the control group in the achievement test and the measure of motivation as a result of their use of the mobile micro-learning strategy. Bakır (2014) investigated the impact of the micro-learning strategy on developing the teaching skills of preservice science teachers. The study sample consisted of (97) teachers as one experimental group. The study found a significant impact of the micro-learning strategy on teaching skills in the dimensions of classroom management implementation skills, time management, effective planning, communication, and lesson evaluation skills. The teachers' attitudes as found in the questionnaire were positive towards the microlearning strategy. Yildirim (2020) identified the effect of applying augmented reality on developing achievement in science. The study sample consisted of (63) students from the seventh grade of secondary school, who were divided into two groups, an experimental group using the augmented reality application, and a control group that used traditional education. The study found the superiority of the experimental group that used the application of augmented reality over the control group that used traditional education in the post-application of the achievement test. Azi and Gemseddin (2020) explored the impact of applying augmented reality on developing achievement and attitudes in social studies. The study sample consisted of (60) fifth-grade students, who were divided into two groups, an experimental group that uses the augmented reality application, and a control group that uses traditional education. The study found that the experimental group that used the application of augmented reality scored better than the control group that used traditional education in the post-application of the achievement test. The results also revealed that the attitudes of the experimental group students were positive towards using the application of augmented reality in education. Wahyu, Suastra, Sadia and Suarni, (2020) investigated the impact of a mobile-based augmented reality application supported by the stem entrance on the development of scientific literacy and 
achievement among elementary school students. The study sample consisted of (516) students, who were divided into two groups, an experimental group that used the augmented reality application, and a control group that used traditional education. The study found that the experimental group that used a mobilebased augmented reality application supported by the stem entrance had a better performance than the control group that used traditional education in the post-application for scientific literacy questionnaire and achievement test. Sáez-López, Cózar-Gutiérrez, González-Calero and Gómez Carrasco (2020) identified the impact of applying augmented reality on developing the practices of future teachers for the elementary stage. The study sample consisted of (87) teachers, as one experimental group. The study concluded through the questionnaires that were distributed to the study sample that the application of augmented reality helped in developing the practices of future primary school teachers in terms of increasing their enthusiasm towards employing augmented reality applications in teaching.

These previous studies dealt with various variables related to the micro-learning strategy and augmented reality. The current study is distinguished by its focus on uncovering the effectiveness of a training program based on the micro-learning strategy in developing the skills of using augmented reality applications among science teachers in Jeddah. Therefore, the current study aims to show the importance of the micro-learning training strategy and its multiple characteristics and advantages in developing the skills of using augmented reality applications for science teachers during service.

The study attempts to answer the following questions:

1. What is the effectiveness of a micro-learning strategy-based instructional program in developing the cognitive dimension of the skills of using augmented reality applications among science teachers in Jeddah?

2. What is the effectiveness of a micro-learning strategy-based instructional program in developing the performance dimension of the skills of using augmented reality applications among science teachers in Jeddah?

\section{Methodology}

Design

The study used the semi-experimental approach to identify the effectiveness of the independent variable (a micro-learning strategy-based instructional program) on the dependent variable represented by (skills of using augmented reality applications) among science teachers in Jeddah. The study sample consisted of (42) male teachers, who were randomly selected from middle school science teachers from schools in the Education Office in North Jeddah, Kingdom of Saudi Arabia. The study was based on the semi-experimental approach based on the one experimental group (pre/post application). The two study tools (the achievement test - the observation card) were applied to the study group, then the experimental treatment was applied (a micro-learning strategy-based instructional program). The tools (achievement test observation card) were also reapplied after conducting the treatment.

\section{Instruments}

\section{Achievement test}

The achievement test was designed to measure the level of the study sample in the cognitive dimension of the skills of using augmented reality applications. It was designed as a multiple-choice test, and it was built in light of Bloom's cognitive levels. Its validity was verified by presenting it to a list of judges. The coefficient of stability according to the Cronbach alpha equation was $(0.828)$, which was a high value. The achievement test became in its final form consisting of (36) items distributed on the scientific content of the training program based on the micro-learning strategy.

\section{The Observation Card}

The observation card targeted the skillful performance of the Eyejack Augmented Reality application skills for middle school science teachers. The items of the observation card were formulated in light of the Eyejack Augmented Reality application skills. The total score on the card was 84 . The validity was verified 
by presenting it to a list of judges, who presented their comments. The reliability coefficient was calculated using the Cooper equation (Cooper, 1974). The average agreement of the observers on the teachers' performance was $(93.33 \%)$, and the reliability coefficient was high, thus proving that the card was usable and applicable to the study sample as a measuring tool.

\section{Results}

\section{Results of the First Question}

What is the effectiveness of a micro-learning strategy-based instructional program in developing the cognitive dimension of the skills of using augmented reality applications among science teachers in Jeddah?

To answer the first question of the study, the first hypothesis of the study was tested, which states, "There is no statistically significant difference at $(0.05)$ between the mean scores of the study group in the pre and post-application of the achievement test related to the skills of using augmented reality applications."

To test this hypothesis, the (T) test was used for the paired sample t-test, and the results are shown in Table (1).

Table 1. The difference between the mean scores of the study group in the pre and post-application of the achievement test for the skills of using augmented reality applications

\begin{tabular}{lcrrlrl}
\hline \multicolumn{1}{c}{$\begin{array}{c}\text { Applicati } \\
\text { on }\end{array}$} & $\begin{array}{l}\text { Mean } \\
\text { score }\end{array}$ & $\begin{array}{c}\text { Standard } \\
\text { deviation }\end{array}$ & No. & $\begin{array}{l}\text { Freedom } \\
\text { value }\end{array}$ & T value & Sig. \\
\hline $\begin{array}{l}\text { Pre } \\
\text { Application }\end{array}$ & 14.05 & 2.378 & 42 & 41 & & \\
\cline { 1 - 4 } $\begin{array}{l}\text { Post } \\
\text { Application }\end{array}$ & 33.40 & 2.001 & 42 & & 41.780 & $\begin{array}{l}\text { Significant } \\
\text { at (0.05) }\end{array}$ \\
\hline
\end{tabular}

Table 1 shows that the cognitive dimension has increased in the post-application of the achievement test for the skills of using augmented reality applications. The mean score of the pre-application was (14.05) and for the post-application was (33.40). Therefore, there was a statistically significant difference at (0.05) between the mean scores of the study group in the pre and post-application of the achievement test related to the skills of using augmented reality applications.

Results of the Second Question

What is the effectiveness of a micro-learning strategy-based instructional program in developing the performance dimension of the skills of using augmented reality applications among science teachers in Jeddah?

To answer the second question of the study, the second hypothesis of the study was tested, which states, "There is no statistically significant difference at $(0.05)$ between the mean scores of the study group in the pre and post-application of the observation card related to the skills of using augmented reality applications."

To test this hypothesis, a T-test was used for the paired sample t-test, and the results are shown in Table (2).

Table 2. The difference between the mean scores of the study group in the pre and post-application of the observation card for the skills of using augmented reality applications

\begin{tabular}{|c|c|c|c|c|c|c|}
\hline Application & $\begin{array}{l}\text { Mean } \\
\text { score }\end{array}$ & $\begin{array}{l}\text { Standard } \\
\text { deviation }\end{array}$ & No. & $\begin{array}{l}\text { Freedom } \\
\text { value }\end{array}$ & $\mathrm{T}$ value & Sig. \\
\hline $\begin{array}{l}\text { Pre } \\
\text { Application }\end{array}$ & 25.33 & 3.811 & 42 & 41 & \multirow{2}{*}{86.635} & \multirow{2}{*}{$\begin{array}{l}\text { Significant at } \\
(0.05)\end{array}$} \\
\hline $\begin{array}{l}\text { Post } \\
\text { Application }\end{array}$ & 79.40 & 2.678 & 42 & & & \\
\hline
\end{tabular}

Table 2 reveals that the performance aspect is high in the post-application of the observation card for the skills of using augmented reality applications. The mean score of the pre-application was (25.33) and for 
the post-application was (79.40). Therefore, there was a statistically significant difference at $(0.05)$ between the mean scores of the study group in the pre and post-application of the observation card related to the skills of using augmented reality applications.

\section{DISCUSSION}

The current study found that there is a statistically significant difference at (0.05) between the mean scores of the study group in the pre and post-application of the achievement test and the observation card related to the skills of using augmented reality applications. The differences were in favor of the postapplication. These results are due to the importance of the micro-learning strategy in conveying the training message through various digital media to convey ideas and information. These digital media act as multiple stimuli linking the trainee's memory with the material presented and make the trainee focus attention on the training content, leading to better training and development of the cognitive and performance side of the skills of using augmented reality applications. The micro-learning strategy also provided an active and rich training environment in various training resources that raise the cognitive structure of the trainee, increase his motivation for training, and achieve better training for practical skills. Therefore, displaying the skill and its details through the micro-learning strategy achieved better training than displaying it traditionally. The micro-learning strategy contributed to preventing distraction and increasing the element of excitement, which led to the development of skills of using augmented reality applications among middle school science teachers.

The results of the current study agree with Wali (2020), which confirmed the effectiveness of the microlearning strategy in developing achievement and self-directed learning skills. The results are also consistent with Ahmad (2019), which concluded that there is a significant impact of using WhatsApp as a tool for the micro-learning strategy for the development of achievement and the attitudes of learners towards its use in education. These findings are also consistent with other studies (Faraj, 2019; Nikou \& Economides, 2018; Bakır, 2014). All of these studies showed the impact of the electronic micro-training technology via the web on the development of the knowledge and performance aspect of the competencies of designing e-learning strategies among secondary education teachers. These studies also showed the effectiveness of the microlearning strategy in developing teaching skills among science teachers before service.

\section{Recommendations}

In light of the findings of the current study, the study recommends the following:

1. Using the micro-learning strategy to provide practical solutions to training and education problems in line with modern technological development.

2. Directing the attention of decision-makers in charge of preparing training programs at the Ministry of Education in the Kingdom of Saudi Arabia to use the micro-learning strategy as one of the training methods due to the ability of this strategy to take into account individual differences among trainees and its effectiveness in developing various performance skills.

3. Using the training program based on the micro-learning strategy that was designed and produced to develop the skills of using augmented reality applications among science teachers in the Kingdom of Saudi Arabia.

There are specific limitations to this study, which can be summarized as the following:

1. Thematic limitations: The study is limited to the skills to using augmented reality applications using the EyeJack Augmented Reality app.

2. Time limitations: This study was conducted in the first semester of the academic year 2020-2021.

3. Spatial limitations: The study was applied to middle schools - the Education Office in North Jeddah.

4. Human limitations: The study was restricted to a group of science teachers at the intermediate level the Education Office in North Jeddah, Kingdom of Saudi Arabia.

\section{References}

Abu Khotwa, A. A. (2020). The Interaction between video cue patterns and its display time in a mobile micro-training environment and its effect on the development of instructional design skills for a flipped classroom, the attitude towards the training environment, and the reduction of cognitive load for teachers. Scientific Journal of the Egyptian Association for Educational Computers, 8(1), 379-468. DOI: $\quad 10.21608 / E A E C .2020 .27957 .1021$. 
Ahmad, N. (2019). Impact of WhatsApp as a micro-learning tool on instruction. E-Leader International Journal, 14(1), 1-19. Retrieved from: http://www.g-casa.com/conferences/tokyo/paper pdf/Ahmad.pdf.

Akçayır, M. \& Akçayır, G. (2017). Advantages and challenges associated with augmented reality for education: A systematic review of the literature. Educational Research Review. 3(20), 1-11. https://doi.org/10.1016/j.edurev.2016.11.002.

Alkhamisi, A. \& Monowar, M. (2013). Rise of augmented reality: current and future application areas. International Journal of Internet And Distributed Systems. 22(3). 25-34. http://dx.doi.org/10.4236/ijids.2013.14005.

Al-Shami, E. A \& Al-Qadi, L. M. (2017). The effect of a training program to use augmented reality techniques in the design and production of electronic lessons for the female student teacher at the Faculty of Home Economics, Al-Azhar University. Journal of the Faculty of Education-Menoufia University, 4 (1), 124-153.

Al-Zein, H. A. (2018). A proposed educational program to develop students' skills in designing augmented reality technology among students of Princess Nourah Bint Abdulrahman University and its impact on increasing their learning motivation. Al Fath Magazine. 74(1), 71-74.

Arici, F., Yildirim, P., Caliklar, Ş., \& Yilmaz, R. M. (2019). Research trends in the use of augmented reality in science education: Content and bibliometric mapping analysis. Computers \& Education, 142, 103- 109. https://doi.org/10.1016/j.compedu.2019.103647.

Azi, F. \& Şemseddin, G. (2020). Effects of augmented reality applications on academic success and course attitudes in social studies. Shanlax International Journal of Education, 8(4), 27- 32. DOI: https://doi.org/10.34293/ education.v8i4.3300.

Bakır, S. (2014). The effect of microteaching on the teaching skills of pre-service science teachers. Journal of Baltic Science Education. 13(6), 789- 801.

Billinghurst, M., \& Dünser, A. (2012). Augmented reality in the classroom. Computer, 45(7), 56-63.

Chen, C.-M., \& Tsai, Y.-N. (2012). Interactive augmented reality system for enhancing library instruction in $\begin{array}{llllll}\text { elementary schools. Computers } \& \text { 638-652. } & \text { Education. }\end{array}$ https://doi.org/10.1016/j.compedu.2012.03.001.

Chen, W. (2014). Historical Oslo on a handheld device - A mobile augmented reality application. Procedia Computer Science. 35(21). 979 - 985. https://doi.org/10.1016/j.procs.2014.08.180.

Díaz, R.P., Caeiro, M., López, J. \& Vilas, a. (2021). Integrating micro-learning content in traditional e-learning platforms. Multimedia Tools and Applications, 1-31. https://doi.org/10.1007/s11042-020-09523-z

Duman,T. \& Karagöz,S. (2016). An evaluation of Turkish teacher education system compared to other models in different countries. International Journal of Educational Research Review,1(1),1-13.

Emerson, L. C., \& Berge, Z. L. (2018). Microlearning: Knowledge management applications and competencybased training in the workplace. UMBC Faculty Collection. https://doi.org/10.34105/j.kmel.2018.10.008

Eyong,E,I., Ugada,C. \& Aminu,A. (2020). Indicators of improved achievement of students' in mathematics. The Universal Academic Research Journal,2(1), 29-37.

Faraj, S. H. (2019). Micro-electronic training technology via the web and its impact on the development of the knowledge and performance side of the competencies of designing e-learning strategies among secondary education teachers. Educational Technology, a series of refereed studies and research. Egyptian Association for Education Technology.29 (4), 214-300.

Ghavifekr, S. \& Rosdy, W.A.W. (2015). Teaching and learning with technology: Effectiveness of ICT integration in schools. International Journal of Research in Education and Science (IJRES), 1(2), 175-191.

Gómez, M.D., \& Paredes, M. (2019) Augmented reality as a methodology to development of learning in programming. In: Botto-Tobar M., Pizarro G., Zúñiga-Prieto M., D’Armas M., Zúñiga Sánchez M. (eds) Technology Trends. CITT 2018. Communications in Computer and Information Science, vol 895. Springer, Cham. https://doi.org/10.1007/978-3-030-05532-5 24

Hesse, A., Ospina, P., Wieland, M., Yepes, F.L., Nguyen, B., and Heuwieser, W. (2019). Microlearning courses are effective at increasing the feelings of confidence and accuracy in the work of dairy personnel. Journal of Dairy Science, 102(10), 9505-9511. https://doi.org/10.3168/jds.2018-15927

Hug, T., Lindner, M., \& Bruck, P. A. (2006). Micromedia \& e-Learning 2.0: Gaining the big Picture. Proceedings of Microlearning Conference (p. 332). İnnsbruck university press. 
Kävrestad, J., \& Nohlberg, M. (2019, August). Using context based micro training to develop OER for the benefit of all. In Proceedings of the 15th International Symposium on Open Collaboration (pp. 1-10). https://doi.org/10.1145/3306446.3340814

Jomah, O., Masoud, A. K., Kishore, X. P., \& Aurelia, S. (2016). Micro learning: A modernized education system. BRAIN. Broad Research in Artificial Intelligence and Neuroscience, 7(1), 103-110. https://www.brain.edusoft.ro/index.php/brain/article/view/582

König, j., Jäger-Biela, d. \& Glutsch, n. (2020) Adapting to online teaching during COVID-19 school closure: Teacher education and teacher competence effects among early career teachers in Germany, European Journal of Teacher Education, 43(4), 608-622. https://doi.org/10.1080/02619768.2020.1809650

Kulkarni, S. \& Takawale, N. (2016). Comparative study of augmented reality and virtual reality. International Journal of Innovative Research In Computer And Communication Engineering. 4(1). 1-6.

Mahmud, I \& Rawson, s. (2013). Micro teaching to improve teaching method: An analysis on students' perspectives. Journal of Research \& Method in Education, 1(4), 69- 76.

Matcha, W. \& Rambli, D. (2013). Exploratory study on collaborative interaction through the use of augmented reality in science learning. Procedia Computer Science. 25.144 - 153. https://doi.org/10.1016/j.procs.2013.11.018

Nikou, s. \& Economides, a. (2018). Mobile-based micro-learning and assessment: Impact on learning performance and motivation of high school students. Journal of computer-assisted learning, 34(3), 269278. https://doi.org/10.1111/jcal.12240

Nikou, S. (2019). A micro-learning based model to enhance student teachers' motivation and engagement in blended learning. Society for Information Technology and Teacher Education International Conference, Association for the Advancement of Computing in Education (AACE), 509-514.

Sáez-López, J., Cózar-Gutiérrez, R., González-Calero, J. \& Gómez Carrasco, C. (2020). augmented reality in higher education: An evaluation program in initial teacher training. Education Sciences, 10(2), 26-38. https://doi.org/10.3390/educsci10020026

Shail, M. (2019). Using micro-learning on mobile applications to increase knowledge retention and work performance: A review of literature. Cureus, 11(8), 2 -7. DOI: $10.7759 /$ curious.5307

Tschida, C., Hodge, E., \& Schmidt, S. (2016). Learning to teach online: Negotiating issues of platform, pedagogy and professional development. In V. Wang (Ed.), Handbook of research on learning outcomes and opportunities in the digital age (pp. 664-684). Hershey, PA: Information Science Reference. DOI: 10.4018/978-1-4666-9577-1.ch029

Wahyu, Y., Suastra, I. W., Sadia, I. W., \& Suarni, N. K. (2020). The effectiveness of mobile augmented reality assisted STEM-Based learning on scientific literacy and students' achievement. International Journal of Instruction, 13(3), 343-356.

Wali, M. F. R. (2020). Designing a mobile micro-learning program based on interactive video "Synchronous and Asynchronous" and its effectiveness in developing achievement and self-directed learning skills among the faculty of education students. The Educational Journal: Sohag University - College of Education, 80. 1301-1397.

Yildirim, F.S. (2020). The effect of the augmented reality applications in science class on students' cognitive and affective learning. Journal of Education in Science, Environment and Health (JESEH), 6(4), 259267. https://doi.org/10.21891/jeseh.751023 